\title{
The Mole and the Mallet: Islamic State and al-Qaeda in the 'Thirty Years' War' in the Middle East
}

\section{Lars Erslev Andersen}

Danish Institute for International Studies, http://www.diis.dk

\begin{abstract}
This article investigates the developments of al-Qaida and The Islamic State in the context of the war on terror. The Iraq war 2003 2010, including the US Counterinsurgency strategy implemented in Iraq in 2007 onwards, together with the political developments in Iraq after the US withdrawal of combat troops at the end of 2011 is seen as the breeding ground for Islamic State in Iraq and thus for establishment of the Nusra Front (al-Qaida) in Syria. The chapter argues that without political developments based on reliable states in the Arab Middle East there is no solution in sight for ending the conflicts and wars in the region.
\end{abstract}

Keywords: Iraq, Syria, Islamic State, al-Qaida, al-Nusra, War on Terror.

\section{Introduction}

Tivoli Gardens in Copenhagen has an arcade game named 'Whack-A-Mole.' The game involves competing about who can hit most moles with a mallet in the shortest period of time. You cannot win against the moles, as they keep popping up from their holes, but you can hit most moles in the shortest period of time. If the moles symbolize al-Qaeda (AQ) and Islamic State (IS), and the mallet symbolizes the military instrument chosen by the West to defeat these two terrorist groups in the Middle East, 'Whack-A-Mole' illustrates quite well how the mallet, the military instrument, cannot win against the moles, al-Qaeda and Islamic State. The game is kept going by feeding money into the machine. Obviously, the big question in the war against terrorism is what keeps AQ and IS going? The disheartening conclusion is that part of the explanation is the way in which the war against terrorism has been organized in the Middle East and elsewhere, using the mallet. Another and just as important explanation is the struggle for power, political influence and resources in the authoritarian states 
in the Middle East which, with the Sunni-Shia conflict orchestrated by the two regional 'super powers,' Saudi Arabia and Iran, is tearing the Middle East apart. The situation resembles a Middle Eastern reconstruction of the Thirty Years' War in Europe.

\section{Current Status}

However, the war against $\mathrm{AQ}$ and Taliban and against the Middle Eastern dictators, Saddam Hussein and Muammar Gaddafi, has fueled the Middle Eastern conflict. This is the lesson learned from 15 years of war against terrorism in the Middle East. The war was initiated by the bombing of AQ's training camps in the mountains of Tora Bora in Afghanistan, it continued with wars in Iraq and Libya, and has now returned to Iraq and a new war in Syria. AQ has also returned, particularly in Syria and Yemen, but also to other countries. Moreover, Islamic State has spread to areas such as Africa, Yemen, Afghanistan and Pakistan, and has established training camps in Syria to train Europeans who return to Europe as terrorists, as we have seen in Paris in November 2015 and Brussels in March 2016. It is noteworthy that the war against terrorism has contributed to moving terrorist training camps from Afghanistan to Syria, and thereby closer to Europe.

Thus in 2016, we can conclude that AQ, which many people, including the author of this article, considered defeated in 2011 following the killing of Osama Bin Laden, perhaps once again is becoming a dangerous global terrorist organization with declared ambitions of hitting targets in the West as well. Following the death of Osama Bin Laden in May 2011, and the killing of many of the infamous AQ leaders in the drone war intensified by Barack Obama when he became President in 2009, many people concluded that AQ had been defeated and were singing their final swan song. ${ }^{1}$ However, others warned that $A Q$ could return and that small $A Q$ networks still existed in the Middle East, which could regain their momentum under the right conditions, and in the right context. ${ }^{2}$ They were right, although those who had declared AQ as dying were not entirely wrong. Today a very different $A Q$ is setting the agenda compared to the AQ that ruled under their great leader, Osama Bin Laden. The death sentence over $A Q$ has proven to be true in terms of $A Q$ 's senior leadership. Ayman al-Zawahiri is the last of the great leaders who formed $A Q$, however he does not have the authority that he had in AQ's heyday.

1 See, for example, Peter L. Bergen, “Epilogue: The Twilight of Al-Qaeda," in Peter L. Bergen, Manhunt. The Ten-Year Search for Bin Laden from 9/11 to Abbottabad (New York: Broadway Paperbacks, 2012).

2 Katherine L. Zimmerman, “Testimony: AQAP's Role in the al Qaeda Network: Statement before the House Committee on Homeland Security Subcommittee on Counterterrorism and Intelligence on "Understanding the Threat to the Homeland from AQAP," American Enterprise Institute for Public Policy Research (AEI), 18 September 2013, available at http://www.criticalthreats.org/al-qaeda/zimmermantestimony-aqaps-role-al-qaeda-network-september-18-2013. 


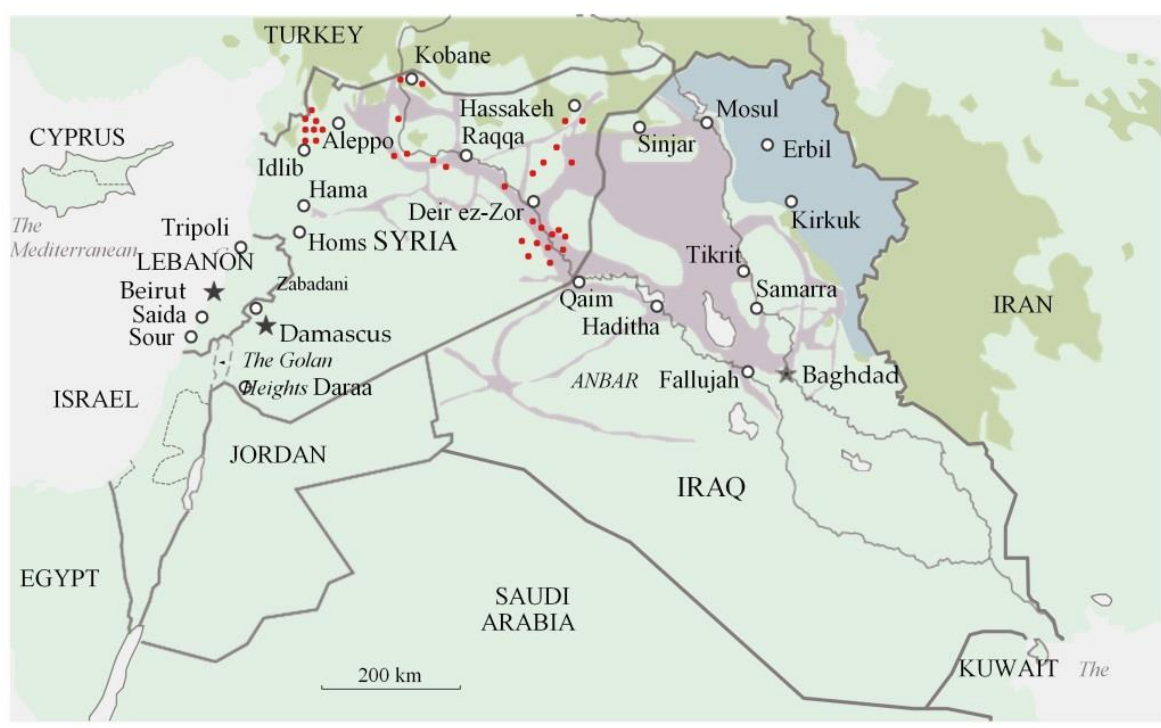

Sources: Institute for the Study of War; Dr M Izady at Gulf2000/Columbia University; The Economist

Areas in which IS is operating

Kurdish populated areas

Kurdish controlled areas

US and coalition air attacks

Figure 1: Map of Syria and Iraq.

Zawahiri is still making statements, regularly with regard to conditions in Syria, and he sends letters with orders to the leaders of the regional AQ groups, such as Abu Muhammad al-Julani, the leader of Jabhat al-Nusra, who courteously distributes the letters to his people, but who does not hesitate to raise questions about the orders in his own statements and interviews (e.g. to the Arabic satellite channel al-Jazeera). However, al-Julani is usually loyal to the ageing $A Q$ leader. When Zawahiri in June 2015 suggested that Jabhat al-Nusra (also known as the al-Nusra Front) should stop planning terrorist attacks on the West, al-Julani backed him up, declaring on al-Jazeera that Jabhat al-Nusra "currently does not regard Syria as a base for attacks on the West." However, he added that the objective in Syria "is not only to get rid of the Bashar a-Assad regime, but also something greater," i.e. a Sharia-based Islamic state and, in the long term, a caliphate (quotes from Charles Lister). ${ }^{3}$ A mysterious group of

3 This article owes a great deal to the very detailed presentation by Charles Lister based on primary sources, personal interviews and extensive knowledge about Syria and Jihad networks: Charles Lister, The Syrian Jihad. Al-Qaeda, The Islamic State and the Evolution of an Insurgency (Oxford: Oxford University Press 2015). 
AQ operators has travelled to Syria from Yemen and Afghanistan, where they have formed a clandestine group. According to Charles Lister, Syria researcher, Jabhat al-Nusra's own people refer to the group as the 'Wolves,' whereas the $\mathrm{CIA}$ has named the group the 'Khorasan Group.' ${ }^{4}$ This was the group whose terrorist plans against the West Zawahiri wanted to stop, because the activities of the group triggered the US bombings of the Idlib Governorate in Syria, in which Jabhat al-Nusra is based.

In addition to destroying Jabhat al-Nusra in the fight against Bashar al-Assad, which, according to Zawahiri, is AQ's primary task in Syria, US bombs hit civilians, and this exacerbates the risk of locals joining other groups than Jabhat al-Nusra. However, al-Julani has not stopped the 'Wolves,' because their specific skills may become useful in future, e.g. if the West intensifies the war against $A Q$ (alias the al-Nusra Front) in Syria.

Osama Bin Laden's actual operational influence was already on the wane in his final years in his self-imposed exile in Abbottabad, Pakistan, where he was hiding from US agents and advanced satellite surveillance. Bin Laden communicated through a courier with regional AQ leaders in North Africa, on the Horn of Africa, in Yemen and elsewhere, but they rarely followed his advice and orders. ${ }^{5}$ As mounting pressure from the US drone campaign began to cause AQ's senior leadership to fall apart, authority and autonomy grew in the regional leaders, whose focus was on the regional conflicts in which they were and are involved. As AQ's senior leadership withered, $A Q^{\prime}$ 's global terrorist actions-and thus the 'existential threat' that the organization posed according to the Americans-was minimized and transformed to regional terrorism which was not a direct threat against either the US or Europe. The strength that AQ has regained in Syria now involves an actual risk that, in the long term, the organization could once again become a global threat. This is partly due to the monomaniac war against IS as, in the shadow of this war, AQ is winning support and gaining strength, just as we saw when Russia began its offensive in Syria in September 2015. Even though AQ is very different now-less centrally controlled and with a more regional approach, and with new names such as Jabhat alNusra-it is back in the game with a new strategy that may be even more dangerous in the Middle East and to the West than the old centrally controlled strategy under Osama Bin Laden, which primarily targeted the US, and is aiming to remove the superpower from the Middle East.

With the return of $A Q$ and IS, which, although under pressure in Iraq and Syria, are gaining ground elsewhere and have documented their intention and ability to organize terrorist actions in Europe, the terrorist threat seems to be steadily increasing, 15 years after the war against terrorism began. This article

Lister, The Syrian Jihad, 201.

5 Nelly Lahoud, Stuart Caudill, Liam Collins, Gabriel Koehler-Derrick, Don Rassler, and Muhammad al-'Ubaydi, Letters from Abbottabad: Bin Laden Sidelined? (West Point, NY: The Combating Terrorism Center at West Point, May 2012), available at https://www.ctc.usma.edu/posts/letters-from-abbottabad-bin-ladin-sidelined. 
describes the history and background of IS and outlines and assesses the development of $A Q$ over the past five years.

The changed $A Q$, in which regional divisions are becoming ever more independent from AQ's central leadership, is illustrated quite well by Jabhat alNusra's official break with AQ in late July $2016 .{ }^{6}$ There had long been rumors, or at least since May 2016, that Jabhat al-Nusra, the strong insurgent militia in Syria, would break with $A Q$ in order to be able to act more flexibly in relation to other Islamist rebel groups in Syria. So far, these groups had (officially) refrained from joining forces with Jabhat al-Nusra because of the group's connection to AQ. Connection to AQ prevents participation in ceasefire negotiations, as the international players will not negotiate with AQ groups. In May 2016, alZawahiri announced that he would have no objection to Jabhat al-Nusra breaking with $A Q$ and instead concentrating on the fight in Syria. However, he stressed that the two groups would still have a common future goal to establish a caliphate. In July 2016, Jabhat al-Nusra's leaders announced that the group had broken with $A Q$ and would change its name to Jabhat Fatah al-Sham. This article describes the development of Jabhat al-Nusra up to the break with $A Q$ in July 2016.

\section{The Iraq War}

The Iraq war in particular is key in understanding the situation currently unfolding in Iraq and Syria, and thus in understanding why IS and AQ have returned as global terrorist threats after the threat seemed to have been almost eliminated around 2011.

When Bashar al-Assad took over from his father in 2000, Syrian intelligence services tried to expand Syria's power by establishing contact to various Islamist networks and $\mathrm{AQ}$ groups, which were emerging in the Iraq/Syria border area. The idea was partly to make life as miserable as possible for the Americans in Iraq on the "if they're busy fighting there, they'll leave us alone" basis, and partly to divert attention from internal problems and to export Jihadists to Iraq. When the war in Iraq broke out in March 2003, Islamist groups and networks in Syria became key players in the recruitment of foreign fighters, in particular for the insurgency against the US-led coalition. The Syrian border area towards Iraq became a hub in the organization of cross-border traffic, but it also became a reception area, in which training camps were established. Several of the major operations in Iraq were organized by networks in Syria. The Syrian intelligence services let this happen, but had very little control over the development. ${ }^{7}$

\footnotetext{
6 "Al-Nusra leader Jolani announces split from al-Qaeda. Al Jazeera obtains exclusive video of Abu Mohammed al-Jolani, saying group's name has changed to Jabhat Fath al Sham," Al Jazeera, 29 July 2016.

7 Lister, The Syrian Jihad, 31ff
} 
Similarly, in Iraq under Saddam Hussein, the Iraqi intelligence services had tried using militant Islamist groups to promote their interests. ${ }^{8}$ This meant that before the war began in 2003, there were already links between the Syrian and Iraqi intelligence services and Jihadi groups. These links saw further consolidation when Saddam Hussein's officers fled to Syria at the beginning of the war after Paul Bremer, head of the Coalition Provisional Authority in Iraq, ordered the Iraqi army to be disbanded. Thus, Syria played a central role in bringing foreign fighters to Iraq. Moreover, Iraqi rebels could find refuge in Syria and return to the Anbar province. The same dynamics were seen with different Taliban and $A Q$ networks across the Pakistan/Afghanistan border.

As the US counterinsurgency operations from 2007 and 2008 in fact reduced violence considerably in the Iraqi Anbar province, and al-Qaeda in Iraq (AQI) came under major pressure from its members fleeing to Syria, the threat from these networks began to concern the Syrian regime, which phased out its laissez faire strategy towards the Jihadists and imprisoned hundreds of people who had been responsible for bringing foreign fighters into Iraq. According to Charles Lister and other researchers, these were the people that Bashar al-Assad pardoned and released from prisons in March and May 2011 when demonstrations began in Syria. The intention was probably to use these people to stage the Syrian insurrection as 'being controlled by international terrorists,' but instead he reactivated the networks that had been particularly effective in terms of supplying foreign fighters to the insurgency in Iraq, and now they had turned against him and the Damascus government. With the city of al-Zabadani north-east of Damascus as their base, Islamist rebel groups were quickly and efficiently established, and they attracted many sympathizers who had turned against the al-Assad regime with violent attacks that must have taken the Damascus regime completely by surprise. ${ }^{9}$

Bashar al-Assad's narrative that foreign terrorists were behind the Syrian insurrection backfired uncontrollably with deadly consequences. This is where the story of Jabhat al-Nusra, AQ in Syria, begins. However, in fact the Iraqi group Islamic State in Iraq (ISI) sent Julani to Syria to establish the al-Nusra Front. Before we continue with al-Qaeda in Syria, a summary of the Iraqi backdrop is necessary.

\section{IS' roots deep in Iraq}

Prior to ISIL's conquest of Mosul in June 2014, there were plenty of signs that a new global terror threat was developing. The signs were based on two aspects - the political situation in Iraq and the Arab Spring in 2011. However, this development was either toned down or completely overlooked by politicians, the media and intelligence services, who expressed confidence that the Iraqi

8 Amatzia Baram, Saddam Husayn and Islam, 1968-2003. Ba'thi Iraq from Secularism to Faith (Washington, DC: Woodrow Wilson Center Press, 2014)

9 Lister, The Syrian Jihad, 54. 
Islamic State and al-Qaeda in the 'Thirty Years' War' in the Middle East

\begin{tabular}{|l|l|l|l|}
1999 & Name & Leader of the Group & Leader of the Network \\
\hline Jund al-Sham & Abu Musab al-Zarqawi & Abu Musab al-Zarqawi \\
\hline
\end{tabular}

\begin{tabular}{|l|l|l|l|}
$\mathbf{2 0 0 3 / 2 0 0 4}$ & Name & Leader of the Group & Leader of the Network \\
\cline { 2 - 4 } & $\begin{array}{l}\text { Jund al-Sham } \\
\text { Changes name to } \\
\text { Jamaat al-Tawhid } \\
\text { wal-Jihad } \\
\begin{array}{l}\text { Changes name to } \\
\text { Committee for al- } \\
\text { Qaeda in Mesopo- } \\
\text { tamia (AQI) }\end{array}\end{array}$ & Abu Musab al-Zarqawi & Abu Musab al-Zarqawi \\
\cline { 1 - 3 }
\end{tabular}

al-Zarqawi dies

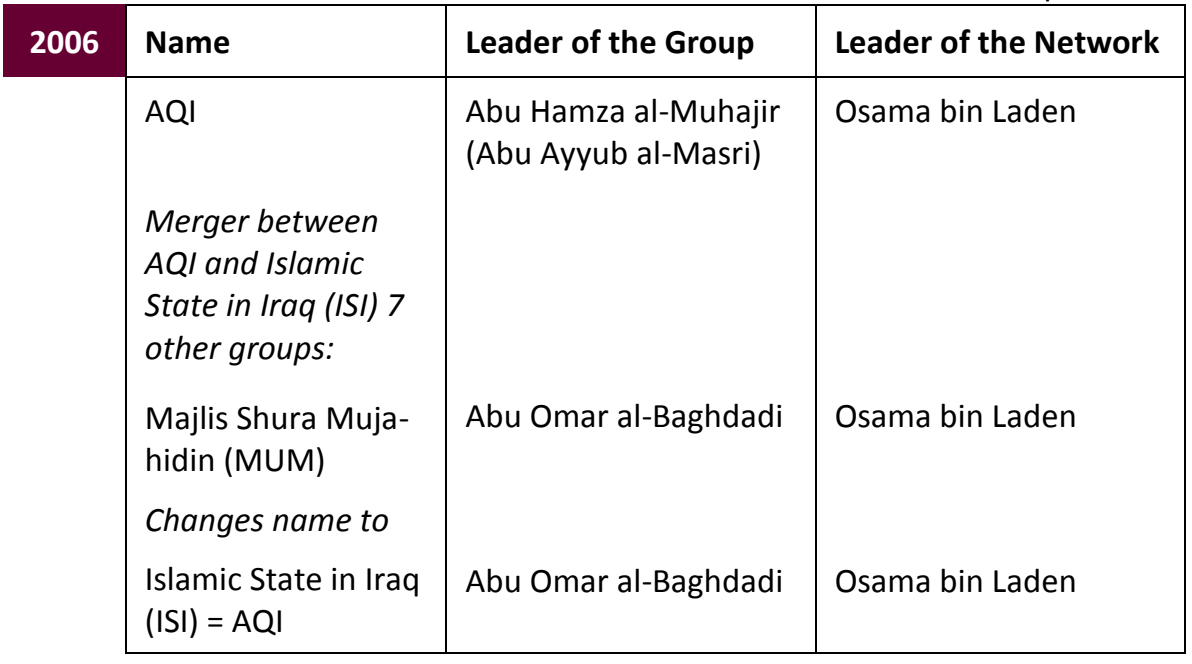

Abu Omar and Abu Hamza die

\begin{tabular}{|l|l|l|l|}
2010 & Name & Leader of the Group & Leader of the Network \\
\hline AQI / ISI & Abu Bakr al-Baghdadi & Osama bin Laden \\
\hline
\end{tabular}

\begin{tabular}{|l|l|l|l|}
\hline 2011 & Name & Leader of the Group & Leader of the Network \\
\hline AQI / ISI & Abu Bakr al-Baghdadi & Ayman al-Zawahiri \\
\hline
\end{tabular}




\begin{tabular}{|l|l|l|l|}
2012 & Name & Leader of the Group & Leader of the Network \\
\hline Jabhat al-Nusra & $\begin{array}{l}\text { Abu Muhammad } \\
\text { al-Julani }\end{array}$ & $\begin{array}{l}\text { Abu Bakr al-Baghdadi / } \\
\text { Ayman al-Zawahiri }\end{array}$ \\
\hline
\end{tabular}

The conflict between ISI and AQ ignites

\begin{tabular}{|l|l|l|l|}
2013 & Name & Leader of the Group & Leader of the Network \\
\hline $\begin{array}{l}\text { Islamic State in Iraq } \\
\text { (al-Baghdadi: Merger } \\
\text { ISI) }\end{array}$ & $\begin{array}{l}\text { Abu Muhammad al-Nusra and } \\
\text { al-Julani } \\
\begin{array}{l}\text { (al-Zawahiri / } \\
\text { al-Julani: Jabhat } \\
\text { al-Nusra) }\end{array}\end{array}$ & $\begin{array}{l}\text { Abu Muhammad } \\
\text { al-Julani }\end{array}$ & Ayman al-Zawahiri \\
\hline
\end{tabular}

Break between ISIL and AQ

\begin{tabular}{|c|c|c|c|}
\hline \multirow[t]{2}{*}{2014} & Name & Leader of the Group & Leader of the Network \\
\hline & $\begin{array}{l}\text { Islamic State / Islamic } \\
\text { caliphate }\end{array}$ & & Abu Bakr al-Baghdadi \\
\hline
\end{tabular}

Figure 2: The Islamic State 'Family Tree.'

government was capable of keeping ISI under control. ISI had otherwise carefully kept accounts of the group's activities, and these were published in statements and annual publications. At the same time, local journalists expressed their concern about ISI's ever-greater power and influence in Iraqi areas dominated by Sunni Muslims, including Mosul, which became a power center for ISI after 2010.

Since 2010, ISI has been run strictly and autocratically by Abu Bakr al-Baghdadi (Ibrahim bin Awwad bin Ibrahim al-Badri al-Radawi al-Husseini al-Samarrai) together with his second in command Hajji Bakr (Samir Abd Muhammad alKhlifawi), who had had a career as a colonel in the military intelligence services under Saddam Hussein. Hajji Bakr was killed in January 2014 in a small town north of Aleppo in Syria. Together with other groups, ISI formed an alliance, as they were furious that they had been marginalized from political power: first by the US-led invasion from 2003 onwards, and then by the Iraqi Prime Minister at the time, Nuri al-Maliki, who systematically kept Sunni Muslims from gaining 
political power, including the 'Sons of Iraq' who helped his government and the US suppress AQ from 2007-2010. ${ }^{10}$

The story behind the formation of IS dates back to 1999, when the Jordanian Jihadist, Abu Musab al-Zarqawi (Ahmad Fadeel al-Nazal al-Khalayleh) was released from prison in Jordan. ${ }^{11}$ In prison, he had become acquainted with Abu Muhammad al-Maqdisi, ${ }^{12}$ a Jordanian-Palestinian scholar of Islam, who had inspired the violent and criminal thug, al-Zarqawi, to Jihad, focusing particularly on Jordan, Iraq, Syria and Palestine (the Levant). In 2004, Maqdisi and alZarqawi had a conflict because of al-Zarqawi's war against the Shia Muslims. AlZarqawi insisted on declaring the Shia Muslims Takfir (apostates) and therefore they had to be killed. This is the exact same situation we see today, with IS calling the Shia Muslims Rafidis (deniers). AQ's senior leaders were also critical towards al-Zarqawi's insistence on attacking the Shia Muslims, and when IS declared the area a Caliphate in 2014, Maqdisi and other prominent Islamists with links to $A Q$ also expressed strong criticism.

When al-Zarqawi was released from prison, he established the Jund al-Sham group, which soon after changed its name to Jamaat al-Tawhid wal Jihad (Unity and Jihad). As early as 1999, the group was responsible for several attempted terrorist actions in Jordan, e.g. the 'Millennium Plot,' which was averted by the Jordanian security services. Al-Zarqawi went to Afghanistan, where he met Osama Bin Laden. He did not become part of $A Q$, but Osama Bin Laden helped al-Zarqawi establish a training camp in Afghanistan around the city of Herat. When the US attacked Afghanistan in 2001, al-Zarqawi's group put up resistance until it fled through Iran and established a new training camp in Iraqi Kurdistan, with close connections to the Ansar al-Islam group which, at that time, was headed by Mullah Krekar (Faraj Ahmad Necmeddin). Back in 1991, Krekar was granted asylum in Norway as a refugee from northern Iraq. However, in 2001, he was in Iraqi Kurdistan with other high-profile Jihadists with connections to $A Q$, and together they established Ansar al-Islam. In his speech to the UN Security Council in February 2003, the American Secretary of State, Colin Powell, referred to Ansar al-Islam and various leaders, who also included Abu Musab al-Suri, when he presented the reasons behind the Iraq war. When the war against Afghanistan unleashed in October 2001, many AQ followers fled to Iraqi Kurdistan and joined Ansar al-Islam. Thus, foreign Jihadists in-

10 Lars Erslev Andersen, "The Locals Strike Back: The Anbar Awakening in Iraq and the Rise of Islamic State," in Reconfiguring Intervention: Complexity, Resilience and the 'Local Turn' in Counterinsurgent Warfare, ed. Louise W. Moe and Marcus-M. Müller (Basingstoke: Palgrave Macmillan, 2017).

11 Beside of Lister, The Syrian Jihad, the narrative of the history of IS is inspired by William McCants, The ISIS Apocalypse. The History, Strategy, and Doomsday Vision of The Islamic State (New York: St. Martin's Press, 2015); and Fawaz A. Gerges, ISIS. A History (Princeton, NJ: Princeton University Press, 2016).

12 Jakob Skovgaard-Petersen, "Heirs of Abu Bakr: On the Ideology and Conception of History in al-Qaeda and Islamic State," Connections: The Quarterly Journal 16, no. 1 (Winter 2017): 25-36, https://doi.org/10.11610/Connections.16.1.02. 
creasingly influenced Ansar al-Islam. Krekar ended up being pushed aside by the recently arrived Arabic veterans from the war in Afghanistan and returned to Norway via the Netherlands. Al-Zarqawi took control of the group and gathered the recently arrived Jihadists and Iraqi rebels in Jamaat al-Tawhid wal Jihad.

Al-Zarqawi became infamous for his extremism and brutality through the gruesome videos in which hostages were decapitated, and through his group's systematic attempt to stir up civil war between Sunni and Shia Muslims e.g. by bombing Shia Muslim mosques and holy sites. The release of a video showing the liquidation of American citizen Nicholas Berg in May 2004 shocked the world as a symbol of al-Zarqawi's brutality. This is alarmingly reminiscent of the notorious violent actions by IS we are seeing today. Today, al-Zarqawi is considered a role model and a martyr, and is admired by IS. He has taken on the same role and status as Osama bin Laden did in AQ. Even though AQ leaders strongly criticized al-Zarqawi's attack on Shia Muslims and would have preferred him to concentrate all his efforts against the Americans and the collaborative Iraqi government, in October 2004 al-Zarqawi's group officially became part of the AQ network under the name Al Qaeda's Jihad Committee in Mesopotamia. The group remained part of $A Q$ even after the death of al-Zarqawi. The current conflict between IS and AQ had already been established with the criticism by AQ leaders of al-Zarqawi's sectarianism. In 2005, a letter from AQ leader, al-Zawahiri, to al-Zarqawi came into the possession of the American intelligence services. In the letter, Zawahiri stresses the necessity of maintaining support from the local population. AQ in Mesopotamia (Al-Qaeda in Iraq, AQI) did not follow this advice, and instead led the cities they controlled rigidly and dogmatically, thus alienating the local Iraqi population. This misreading of the ideology, strategy and situation in Iraqi society led to 'insurgency from below' against $A Q$, headed by a number of Sunni tribal leaders and sheikhs - the Anbar Awakening.

Al-Zarqawi was killed by American forces in a targeted attack on 7 June 2006 north of the city of Baquba in Iraq. Violence in Iraq escalated constantly and rapidly during this period, especially in the Anbar province and around Fallujah - the hub of AQI's insurgency. The conflict with al-Qaeda was aggravated by the death of al-Zarqawi, as his successor, Abu Hamza al-Muhajir, took an oath of allegiance to Abu Omar al-Baghdadi, who shortly before this had been appointed Commander of the Faithful (emir al-muminin) of ISI.

ISI came into existence after Jamaat al-Tawhid wal Jihad had joined forces with five other Jihadi groups and subsequently changed its name to Islamic State Iraq. With his oath of allegiance, Abu Hamza subjugated the AQ army to ISI, which naturally made Osama bin Laden angry. This conflict did not go public, but became known through the documents collected from Osama Bin Laden's house in Abbottabad after US Special Forces killed him in 2011. Osama Bin Laden was furious because AQ considered it premature to declare themselves a state, as the criteria for an Islamic state had yet to be realized. In addi- 
tion, the AQ leader was displeased that Abu Omar al-Baghdadi had assumed command of up to 12,000 warriors without his approval. ISI was earnest about announcing a state, and this is the definitive difference between IS and AQ. IS (ISI at the time) wants to realize an Islamic state right away using violent methods, whereas AQ wants to slowly build the state up from scratch, with $A Q$ at the head. One might expect that Abu Hamza's oath of allegiance to Abu Omar al-Baghdadi would have resulted in ISI no longer being part of AQ. This was probably also what Abu Omar al-Baghdadi thought, but not Bin Laden and Zawahiri. $^{13}$

Nevertheless, ISI was officially part of the AQ network up to February 2014, when the new AQ leader, al-Zawahiri, following a long open conflict, dramatically renounced $\mathrm{Abu}$ Bakr al-Baghdadi in the question about to whom the leader of Jabhat al-Nusra should refer. It is interesting to see that there is a direct link between al-Zarqawi and his disagreement with $A Q$, and the break between $A Q$ and Islamic State today. Thus, AQ and IS have developed quite differently since around 2006. This is particularly apparent in their different interpretations of strategy and image of enemy. Therefore, IS and al-Qaeda should not be viewed as one group. They differ (and always have differed) considerably in many important areas. This is clear from the Abbottabad documents to which al-Zawahiri refers in his criticism of IS. Nevertheless, it is most appropriate to view ISI and $A Q I$ as part of the same organization up to the change of name in April 2014, when Abu Bakr al-Baghdadi, following a conflict with Zawahiri and the leader of the al-Nusra Front, al-Julani, declared Islamic State in Iraq and the Levant (ISIL) the only valid name of the two groups. He was wrong though, as Jabhat al-Nusra, with Zawahiri's blessing, kept operating under the old name.

\section{The New al-Qaeda in Syria: Jabhat al-Nusra}

For a long period from 2007 to 2010 it looked as though ISI/AQI were about to be defeated and eliminated in Iraq. Local tribes were dissatisfied with how AQI foisted its fundamentalist ideology upon them and controlled their local communities and resources. Moreover, they were increasingly under attack by the government army in Baghdad and by Shia Muslim militias.

In other words, they were being attacked on two fronts and they feared that the situation would only worsen if Iran gained even more influence on the government in Baghdad. At the same time, the Americans were changing their strategy from pursuing the enemy, AQI, to protecting the local population. The new US Chief of Command in Iraq, David Petraeus, made a big deal of the fact that these two trends came together. The locals were to hunt down AQI with support, training, weapons and pay from the US. The president at the time, George W. Bush, had been advised to withdraw his troops from Iraq, but instead he increased the number of soldiers by 20,000 and extended the period

13 Lahoud, et al., Letters from Abbottabad. 
in Iraq for an additional 10,000 soldiers who should have otherwise have returned to the US (the Surge). Their task was to protect the local population in order to win their 'hearts and minds' and to train the 'Sons of Iraq' made available by tribal leaders to the Americans in the war against AQI. 'Sons of Iraq' constituted about 100,000 men who fought at a salary of USD 300 a month. The operation, named the Anbar Awakening, was successful in the sense that it sent AQI on the run. Most of them went to Syria, where the intelligence services now saw them as a threat and therefore took firm action against them and sent them to prison together with others from the Syrian Jihad centers. ${ }^{14}$

Some Jihadists were able to escape to Lebanon. In 2005, Syria had been forced out of Lebanon, but still had important interests in the country. The Jihadists migrated, particularly to areas in northern Lebanon around Tripoli, where they infiltrated the Palestinian group supported by Syria, Fatah al-Islam, which, in 2007, in the refugee camp Nahr al-Barad was responsible for fighting against the Lebanese army that killed more than 400 people. When the insurgency had been defeated, some of the Jihadists hid in the Palestinian refugee camp at Ain al-Helweh in southern Lebanon close to the city of Saida. ${ }^{15}$ The alNusra Front and IS rely on these networks with ramifications to Syria and the Anbar province when they recruit fighters. This is a major problem for Palestinians in Lebanese camps who are not interested in being associated with these Jihadi networks. This is also more generally a problem for Lebanon, as the presence of these Sunni Muslim Jihad networks is threatening to move the civil war in Syria into Lebanon in the form of confrontation with Hezbollah which is fighting for the al-Assad regime. So far, together with Hezbollah, the Lebanese army has managed to prevent the Syrian conflict from spreading to Lebanon. However, a major terrorist action by IS in Beirut in November 2015 testifies that there is a risk that the war in Syria will spread to Lebanon. Lebanon has received more than 1.5 million Syrian refugees and, obviously, this is putting a lot of pressure on such a small country.

The Iraqi tribes behind the Anbar Awakening were primarily interested in security and influence on the Baghdad government (and not hearts and minds'). As the Americans had implemented their new Counterinsurgency (COIN) strategy without ensuring loyalty from the Nuri Al-Maliki government in Baghdad, the situation turned upside down when the US withdrew combat troops at the end of 2011. Influenced by Iran and his Shia Muslim power base, Maliki pursued sectarian policies that blocked Sunni Muslims from serving in the army and from gaining power in Baghdad. Already in 2010, when the al-Iraqiya party, which included both Sunni Muslim tribes and secular Shia Muslims, won the election, Maliki deprived them of power and thereby cemented the sectarian line. ${ }^{16}$

14 Lars Erslev Andersen, "The Locals Strike Back."

15 Bernard Rougier, The Sunni Tragedy in the Middle East. Northern Lebanon from alQaeda to ISIS (Princeton, NJ: Princeton University Press, 2015).

16 Lars Erslev Andersen, "The Locals Strike Back." 
The result was an escalation of violence, and a plethora of Islamist groups in $A Q I$ regained their strength and merged with other groups led by the officers who Paul Bremer had sent into the dark in 2003 when he dissolved Saddam Hussein's army. Thus AQI/ISI were back in the game. They built themselves up systematically, e.g. by infiltrating power structures in cities in the Anbar province and by starting a campaign of terror aimed at prisons, through which hundreds of AQ members were released. The goal of ISI was to regain power in Iraq and to create an Islamic state, and from 2012 the group, which by now should rather be called a Sunni Muslim insurgent army, increased in strength. The former leader Omar Abu al-Baghdadi had been killed in 2010 and replaced by Abu Bakr al-Baghdadi who had been released from a US prison in Iraq, Camp Bucca, in 2009. For years, the new leader had been part of the Islamist networks, and he had a PhD in Islamic Sciences from the University of Baghdad. Together with former intelligence officers and other AQ personages, he turned ISI into an insurgent army that, with an effective strategy, mafia-like methods and brutal sectarian violence, became an ever-increasing threat to the regime in Baghdad and to Iraqi Kurdistan.

While ISI was regaining its strength in Iraq, the civil war developed in Syria. In only a few months, the situation changed from demonstrations to escalations of violence, which were primarily due to the regime's brutal reaction to the demand for reform. Officially, the regime in Syria declared that the demonstrations were due to terrorists from outside, and that these terrorists were causing the violence. In order to see this for himself, Bashar al-Assad released some of the Islamists the regime had imprisoned from 2007, and who had been the driving force in recruiting foreign fighters from Syria to Iraq. Like casting out fry to catch fish, Islamists were set free to convince the international community that foreign terrorists were causing the violence and to frighten the local Syrian population. However, the situation immediately came out of control, and the Islamists quickly used their network and organized Islamist-based insurgency against the al-Assad regime.

In Iraq, ISI decided to open a Syrian front and to take part in the Syrian insurgency. Abu Bakr al-Baghdadi delegated the task to Abu Muhammad al-Julani, and activities were financed by ISI and by rich AQ sympathizers in Kuwait and Qatar. Julani, who is Syrian and had had a long career in ISI under al-Zarqawi, was sent to Syria as early as in August 2011. In Syria, he travelled to different rebel towns and formed the group that later became Jabhat al-Nusra. Jabhat al-Nusra was officially declared a Jihadi group with links to al-Qaeda on 23 January 2012. The group quickly became a strong organization which attracted sympathizers from the Gulf, Yemen, North Africa, the US and Europe, including Denmark. Within a short time, Jabhat al-Nusra became one of the strongest and most important militias in the Syrian opposition. Their ideology was close to that of al-Qaeda, which was not surprising given that in 2011 ISI was still a recognized part of the AQ network. The success of Jabhat al-Nusra was partly due to strong discipline, but also a good dose of pragmatism. Thus, 
the goal of Jabhat al-Nusra's fight was to establish an Islamic emirate, and in the long term a caliphate, which was to be run by a Sharia-based ideology, including hudud punishments (cutting off hands, beating, whipping etc.), but the principles were not to be strictly enforced during war. In other words, Sharia and hudud could wait until the future emirate. Jabhat al-Nusra's leaders had learned from AQ's mistakes in the insurgency during the war in Iraq against the US and the new Iraqi leaders following Saddam Hussein. Instead of introducing a strict Sharia codex to the citizens of the villages, cities and areas under the control of Jabhat al-Nusra, the group prioritized security, supplies of oil and petrol to the areas in which they controlled such resources, and protection of local hospitals and health clinics even though patients and staff were secularized and not religious. Jabhat al-Nusra did not repeat $A Q^{\prime}$ s mistake in Iraq; i.e. they did not alienate themselves from the local population in Iraqi cities and towns. Instead, Jabhat al-Nusra took a pragmatic approach in a conscious endeavor to establish a good relationship with the local population in Syria. In the resistance, the group also cooperated with other Syrian insurgent militias, Islamists as well as secular militias, including the Free Syrian Army (FSA), which was formed only a few months before Jabhat al-Nusra. Together with discipline and skilled leadership, this pragmatic approach was probably the foundation for Jabhat al-Nusra's success, both locally and in the recruitment of fighters from outside. There are reports that some fighters joined Jabhat al-Nusra not for political or religious reasons, but because the group was better organized than many of the other rebel militias.

\section{Establishment of ISIL and the Conflict with al-Qaeda}

Jabhat al-Nusra's success was an increasing cause of annoyance for the leaders in ISI, who saw from Iraq that in December 2012 the Syrian sub-division was included on the US list of terrorist organizations, and that the leader, al-Julani, had become the most wanted person in Syria. These were both clear signs of Jabhat al-Nusra's strength in the Syrian insurgency. ISI leaders, who probably feared that Jabhat al-Nusra would develop into an actual rival, tried several times, although unsuccessfully, to pressure al-Julani to declare publicly that he and Jabhat al-Nusra were being controlled by ISI and al-Baghdadi. Finally, on 8 April 2013, after having explained the group's different names since its formation by Abu Musab al-Zarqawi, the leader of ISI, Abu Bakr al-Baghdadi, issued a statement in which he said that Jabhat al-Nusra was an ISI offshoot. ISI had established the group as a front in Syria to create and prepare a future Islamic state, which was to stretch over an area from northern Iraq and into Syria. From then on, both groups would be named ISIL. Neither ISI nor Jabhat al-Nusra would continue as valid names.

Two days later, al-Julani confirmed that al-Baghdadi had ordered the establishment of al-Nusra, and that ISI had supplied al-Nusra with weapons, money and manpower, but that the al-Nusra Front as well as ISI were under AQ's highest-ranking leaders - they were both local AQ groups and had to obey the 
leader, Ayman al-Zawahiri. Abu Muhammad al-Julani continued to swear allegiance to al-Zawahiri and confirmed that nothing had changed, despite Abu Bakr al-Baghdadi's statement two days earlier. This was the start of an open conflict between the Syrian and the Iraqi $A Q$ groups, and ended with a unique confrontation between $A Q$ and what later became known as Islamic State. Supplies of weapons to Jabhat al-Nusra were stopped, and ISIL began to take control of arms depots and areas in which Jabhat al-Nusra had been strong. This took place with brutality and with disregard for the Syrian revolution. The fight against Bashar al-Assad's regime did not have first priority. First priority was to secure control of important areas in Syria in order to maintain a strong position in Iraq.

ISIL did not focus directly on fighting the Assad regime, but primarily on controlling areas from Aleppo, through agricultural areas, strategic points and oil resources, into Iraq. This meant that Assad had no interest in attacking the group with his fighter planes. For a period, he even bought the oil that, strictly speaking, the group had stolen from the Syrian regime. On the other hand, the various rebel militias formed a common front against ISIL, which became completely isolated in Syria at the turn of the year from 2013 to 2014. Attempts to mediate between ISIL and Jabhat al-Nusra failed. On 2 February 2014, this led the AQ leader, Ayman al-Zawahiri, who had initiated the mediation attempts, to officially declare that ISIL was no longer part of the AQ network because of its strategy and unwillingness to cooperate.

This was the first and, so far, only time that an AQ group was excluded from the network, and Ayman al-Zawahiri's declaration caused a stir in international media and was communicated under headlines such as "Who are Isis? A terror group too extreme even for al-Qaida" (The Guardian, June 2014). With the break from al-Qaeda, ISIL engaged in an open war with the entire Syrian opposition, including the Nusra Front. However, in actual fact, in 2014 ISIL became much stronger than the languishing old $A Q$ senior leadership. The conflict briefly led to internal divisions within Jabhat al-Nusra, in which several members who felt more closely connected with al-Baghdadi than with al-Julani left the Nusra Front and joined ISIL. By the time that the conflict between AQ and ISIL went public, ISIL had lost considerable ground in Syria due to the united forces of the other opposition groups. However, during January and February 2014, ISIL regrouped and quickly gained control of strategically important areas and areas with many resources in Deir Ezzor. During the spring of 2014, the group regained areas in eastern Aleppo, and consolidated in al-Raqqa - the main city for the group in Syria.

The fight against al-Assad did not motivate the entire expansion into Syria, but the objective was to counteract a weakening of what became known as Islamic State in June 2014. The overall objective of IS was to complete a broad Sunni-Muslim-based revolution against the government in Iraq in order to establish a caliphate, which, for historical and religiously apocalyptic reasons should cover the area around the city of Dabiq in northern Syria, because reli- 
gious scriptures predict that this is where the final battle is to take place. The expansion was at the same time as ISIL took control of Fallujah and besieged Ramadi in the Iraqi Anbar province. Thus, ISIL quickly gained ground in both Iraq and Syria in spring 2014.

On 10 June 2014, ISIL surprised everyone when they occupied Mosul. On TV, it looked as though rampaging hordes of Jihadists were driving away a large and well-armed Iraqi army, and questions soon arose: how could such a group, estimated to consist of around 3-5,000 men, pester and defeat an entire wellarmed army? Some media could report that only 800 Jihadists had sent 30,000 soldiers on the run (five divisions). However, ISIL's strength should hardly have come as such a great surprise, given the successes of the group earlier in the year in both Iraq and Syria, and not least given how for years the group had systematically consolidated in Sunni Muslim cities in Iraq and gained increasing support from other Sunni Muslim groups and people. As mentioned earlier, local Iraqi journalists and analysts had long been writing about how ISI had taken control of Mosul using terrorist actions and mafia-like methods. In other words, ISIL could so effortlessly take over a large city like Mosul because the group was already in control of most of the city and through terrorist actions had acquired weapons, money, businesses and support networks.

ISIL was not only a Salafist fundamentalist group, but, at least from 2010, a well-run organization with support from many Sunni Muslim militias, an effective strategy and an ideology that they were building a cohesive Islamic state that could deliver on all parameters. This seemed to be attractive to many people in the region, in Europe and elsewhere, as a record number of volunteers flocked to Syria and Iraq. What we saw in Iraq, with ramifications into Syria, was a Sunni Muslim insurgency that was not limited to the brutal Islamic State, but which had much broader support from others, including non-religious groups, who all felt completely abandoned by the government in Baghdad, the Kurdistan Regional Government of Iraq in Iraqi Kurdistan, al-Assad's regime in Damascus, the US and the international community.

\section{The al-Nusra Front and IS}

Jabhat al-Nusra rapidly recovered from the setback from the conflict with IS, in which the Front had to witness a large number of its fighters join al-Baghdadi's troops. Jabhat al-Nusra quickly regained ground, and new recruits joined the group. Jabhat al-Nusra has also been able to cooperate with other Syrian rebel militias, especially Ahrar al-Sham, and at times also the FSA. As mentioned earlier, the Al-Nusra Front had been included on the US list of terrorist organizations in December 2012, and in September 2015, the CIA announced that the al-Nusra Front had formed the Khorasan group, which was the CIA name for the group of $A Q$ veterans who had joined the al-Nusra Front in Syria from Yemen and Afghanistan and according to several sources are now hiding in the Idlib Governorate. Since September 2015, the US has been attacking al-Nusra. Together with France, the Americans have maintained that Jabhat al-Nusra is 
an $\mathrm{AQ}$ group, and that the group therefore cannot be part of negotiations on the future of Syria. Despite this, al-Nusra has continued its pragmatic approach, aiming to defeat the al-Assad regime, and all the evidence shows that the alNusra Front's strategy will succeed in the sense that the group is gaining ever more ground and support in the fight. At the same time, the leader of al-Nusra, al-Julani, maintains that cooperation or even reconciliation with IS is out of the question. The leader of AQ, Zawahiri, has encouraged militias in Syria several times to stop fighting each other and instead focus on the war against the regime in Damascus. When there was heavy fighting over the Yarmouk Palestinian refugee camp in Damascus, IS and the al-Nusra Front fought together against Syrian government forces, which were supported by Palestinian militias under Ahmad Jibril from the PFLP-GC. Therefore, there was speculation that perhaps al-Nusra and IS were approaching each other.

All things considered, fighters from the al-Nusra Front had changed side. Jabhat al-Nusra sprang from IS, and some members will probably still find that they feel more allied with al-Baghdadi than with al-Julani, particularly if an occasion to do so arises. We are likely to see more of such shifts, but in essence there are no indications that the al-Nusra Front and IS are approaching each other. However, there is much speculation about this. In Foreign Affairs, Bruce Hoffman, the famous terrorism researcher and professor at Georgetown University, puts forward four arguments that IS and AQ will merge in an explosive cocktail. But so far, this has been rejected as pure speculation by the parties themselves.

Even though the US and perhaps France have bombed the al-Nusra Front in Syria, Jabhat al-Nusra is benefitting from the fact that the international campaign is primarily aimed at IS. AQ seems to have learned from its mistakes. Instead of foisting their interpretation of the Quran and Sharia on the local population in Syria, AQ is using a more long-term approach and is working on becoming part of society in order to gain support. If the political, economic and power situation does not change radically, the conditions that enable groups and networks such as IS and AQ to return time and time again will prevail, like the moles in Tivoli Gardens in Copenhagen. If the militant Jihad networks are to be combated effectively, it is important to understand the historical, social and political circumstances that breed groups such as AQ and IS, and to address these issues. So far, the war against terrorism has failed to do so.

Spring 2016 still saw several reports that IS is under pressure from a military as well as an economic perspective. The main cities, Mosul, Fallujah and Raqqa, are under siege, and financially IS is increasingly being deprived of revenues from oil sales. Nevertheless, IS is far from broken. Even if IS is broken within the foreseeable future, the networks of Jihadists which have been established throughout the region from Lebanon over Syria to Iraq, will still be present, and so will the problems which to a large extent constitute the basis for the insurgency war and the sectarian conflicts. 


\section{Conclusion: IS, AQ and the 'Thirty Years' War' of the Middle East}

Decisive political change is necessary in both Iraq and Syria in order to allow for new stable governments that can create a society based on the rule of law and secure conditions for Syrians and Iraqis. This is the only condition for effectively combatting extremism in the region. As we saw in 2014, defeating IS in Syria and Iraq starts in Damascus and in Baghdad. In this way, the George W. Bush administration and his neo-conservative advisers were actually right: It takes a change of regime! However, the solution is not, as Bush wanted, to bomb democracy into the Middle East, or what we are seeing now, to bomb IS without thinking about what needs to come next. There is no doubt that a united world against IS would defeat and dissolve a caliphate. In spring 2016, there were many signs and much spin that IS is under pressure. However, as IS is displaced, al-Baghdadi's group is gaining ground in the areas in which the West has already fought wars such as Afghanistan and Libya. It does not take much imagination to see that the current strategy by which the West and Denmark have joined the 'Thirty Years' War' in the Middle East is a Sisyphus project that is almost as promising as hitting a mole with a mallet in Tivoli Gardens.

\section{About the author}

Lars Erslev Andersen is a Senior Researcher at DIIS. He previously served as associate professor in History at University of Southern Denmark (SDU) and Head of the Center for Middle East Studies at SDU. His current research focuses on relations between World Order and War on Terror, US Security Policy related to the Middle East, insurgency in Iraq, and political ramifications of the refugee crisis in the Levant. His recent publications include "The Locals Strike Back: The Anbar Awakening in Iraq and the Rise of Islamic State," in Reconfiguring Intervention: Complexity, Resilience and the 'Local Turn' in Counterinsurgent Warfare, ed. Louise W. Moe and Marcus-M. Müller (Basingstoke: Palgrave Macmillan, 2017) and The Neglected. The Palestine Refugees in Lebanon and the Syrian Refugee Crisis, DIIS Report 2016:12 (Copenhagen and Beirut, 2016). 